Post peer review version of Zehfuss, Maja, "Targeting: Precision and the Production of Ethics", European Journal of International Relations, vol. 17. no. 3 (2011), pp. 543-556 (ISSN: 1354-0661).

\title{
Targeting: Precision and the Production of Ethics
}

War necessarily involves destruction. The development of precision-guided munitions seems to have made it possible to produce intended damage with increasing efficiency and to reduce 'collateral' damage. This has given rise to the expectation that fighting with such weapons reduces the extent of destruction and, crucially, that it is therefore becoming increasingly possible to protect non-combatants during war. This article examines this idea by exploring in some detail what is meant by 'precision' and asking in how far this actually entails protection for non-combatants. The article shows how praise for precision not only produces Western warfare as ethical but also both relies upon and reproduces a particular kind of ethics, based on the notion of non-combatant protection. The conclusion draws together the implications of the faith in precision for how we think about war and challenges the underlying assumption that more precision is better.

\author{
Professor Maja Zehfuss \\ Politics \\ School of Social Sciences \\ The University of Manchester \\ Oxford Road \\ Manchester \\ M13 9PL \\ UK \\ maja.zehfuss@manchester.ac.uk
}


War necessarily involves destruction. ${ }^{1}$ Buildings are blown up, essential infrastructure is destroyed, lives are ended. Some of this damage is very much intended: the destruction of a designated target is, after all, a success in military terms. Other damage, or so we are told, is accidental, or rather - in the phrase that causes so much offence - 'collateral'. ${ }^{2}$ It is therefore fortunate that developments in weapon technology appear to have made it possible to produce the first kind of damage with increasing efficiency and to reduce the second kind of damage. Put differently, 'smart' bombs or precision-guided munitions (PGMs) seem to enable Western militaries to reliably hit ever smaller targets. This has given rise to the expectation that fighting with such weapons reduces the extent of destruction and, crucially, that it is therefore becoming increasingly possible to protect non-combatants during war. 'Smart' bombs, in other words, enjoy a positive reputation and they do so not least because of their alleged ability to reduce the level of unintended non-combatant casualties.

This seems to be an appealing development. If, using our technological ingenuity, we can reduce the destructive effects of warfare - reduce them to the kind of destruction that is an efficient part of warfare in that it delivers the war's objectives - then war is no longer quite the hell it was once seen as. It has therefore been suggested that the increase in precision has ethical significance. Nicholas J. Wheeler claims that the development of precision weapons has 'ameliorated the awful moral choices that faced American and British decision-makers during World War II' (Wheeler, 2002: 216). Ward Thomas similarly argues that evolving technology since the Second World War has made it 'easier to be good' (Thomas, 2001: 172) whilst Theo Farrell represents precision bombing as a 'humane' means of warfare (Farrell, 2005: 161). Such claims are significant not least because, according to Christopher Coker, 'Western societies can now only fight wars which minimise human suffering', including on the side of the enemy (Coker, 2001: 2). That is, war is acceptable only if it is seen as ethical in the sense of causing a very limited amount of death and suffering. 
Yet, despite the compelling story of increasing precision and the related reduction in civilian casualties, it might not be as simple as that. This article examines the idea that precision bombing has made war more ethical. The argument proceeds in four stages. First it traces claims that increasing precision in aerial warfare complemented by greater efforts to avoid collateral damage through targeting processes has made warfare more acceptable in an ethical sense. Second the article examines what is meant by 'precision'; precision is not merely a technical feature of high-tech weaponry but involves wider targeting practices. Destroying a target 'with precision' involves not only the technological capacity to hit the designated aimpoint; it also involves the ability to identify the target and determine its location in the first place. Third the article asks in how far 'precision' actually entails protection for non-combatants. Finally the article shows how the praise for precision not only produces Western warfare as ethical but also both relies upon and reproduces a particular kind of ethics, based on the idea of non-combatant protection. The point of this examination is not to argue the reverse of the claims that are being examined, namely that war has become less ethical due to precision bombing; nor does it defend an alternative ethics. Rather what is at issue here is to make apparent some of the problems with the implicit assumptions as well as at times explicit claims about the benign effects of precision bombing. The conclusion notes the implications of this argument for how we think about war as arguably the idea of hightech weapons enabling ethical war has the scope to make possible a problematic moral - and indeed political - rehabilitation of warfare.

\section{In Praise of Precision}

The 1991 Gulf War made advances in weapon technology visible to the public. According to Thomas W. Smith (2002: 363), the 'war's branded image' was 'the video-arcade footage of a laser-guided missile entering the chimney of an Iraqi Air Force building and flattening the place.' It is hard not to be in awe at the sheer technical sophistication that was required to 
achieve this. Unsurprisingly, the pervasive imagery of such technological accomplishments raised expectations regarding the precision of bombing in contemporary war. Michael Ignatieff (2000: 92) claims that since the moment 'when reporters saw cruise missiles "turning left at the traffic lights" to strike the bunkers of the Iraqi regime, the Western public has come to think of war like laser surgery.' In other words, the Gulf War - or rather its visualisation on Western television screens - suggested that Western militaries are increasingly in control of the devastation caused in war.

More precisely, it seems to have become possible to destroy specific targets. This is impressive not least compared to the early days of aerial bombing when, given the crudeness of the technology used for navigation and weapon delivery, cities were bombed because they were big enough to be hit. As Thomas (2001: 105) explains, in the First World War targets were 'chosen to maximize the chances of hitting something of value, and this meant dropping bombs on cities.' The available technology did not permit the precision required to hit other, smaller targets - such as specific parts of the enemy's infrastructure - that might have had more military significance and the destruction of which might have made a greater contribution to the overall outcome of the war.

The Second World War brought home the implications of this imperfect bombing technology. Cities - on all sides of the conflict and located in different theatres of war became battlefields or, perhaps more accurately, sites of destruction. In the case of German cities the devastation has often, despite its scale, been represented not as the result of deliberate targeting of residential areas in order to affect German morale but as a side-effect of the insufficiently precise bombing of factories and other 'strategic' targets nearby. ${ }^{3}$ The technology used to deliver the bombs was so imprecise that it appears impossible to establish - retrospectively, based on what was hit - what the targets were of the sustained bombing 
campaign against Germany. Mission performance was, Mike Davis (2002: 73) notes, 'measured simply by urban acreage destroyed' and Germany's industrial capacity - if that was the intended target - was not successfully reduced (Garrett, 1993: 161-2).

That cities became battlefields was, of course, not new. Laying siege to cities, for example, is one of the oldest techniques of warfare (Graham, 2004: 166). Nevertheless, cities and those who lived in them had become more exposed; for aircraft could go far behind enemy lines. The combination of the possibility of delivering bombs from the air with the crudeness of targeting technologies led to large-scale destruction. Cities were targeted because it was possible to do so and, crucially, because more militarily significant targets could not be hit reliably. What was targeted was in part a consequence of the available technology. ${ }^{4}$

In his Ethics of Destruction Thomas relates technological progress to the question of normative constraint. More specifically, he examines what he calls the 'bombing norm' - that is, the norm against bombing civilians - and its strength or weakness over time. According to the conventional view, in the Second World War the 'death of the norm was sealed by technological limitations that left belligerents with little choice but to hit the largest and most accessible targets available: enemy civilians' (Thomas, 2001: 89). Put differently, because bombs were available but not sufficiently precise they were used in indiscriminate ways and enemy civilians were, as a result, not protected. Thus, in Thomas's account, aerial warfare in the Second World War was marked by an ethical failure which was directly related to the state of technology.

Thomas's aim is, however, to show that the bombing norm has been revived since. He suggests that the view that legitimate warfare had to avoid large numbers of civilian casualties became increasingly widespread and underlines this with claims about the improved care 
taken to avoid non-combatant casualties in the Korean and Vietnam Wars. In the latter, a complex 'target list review process' involving military commanders and civilians was introduced (Thomas, 2001: 151-5). This development continued in the post-Cold War period. Thomas (2001: 158) draws attention to the coalition air campaign 'joint no-fire target list' in the 1991 Gulf War, which excluded numerous potential targets, for example because they were considered to be culturally or religiously sensitive. Targets were reviewed in order to identify whether there were any schools, hospitals or mosques within a six mile radius. Planning with respect to such targets was to involve 'extreme care' and Thomas claims that where the probability of collateral damage - that is, ' $[\mathrm{u}]$ nintentional or incidental injury or damage to persons or objects that would not be lawful military targets in the circumstances ruling at the time' (Department of Defense 2007) - was assessed as too high they were not attacked. Other measures were also taken to protect civilians, such as selecting particular times, axes of attack and types of weaponry which were believed to reduce the likely number of casualties (Thomas, 2001: 158).

Thus, improvements in technology - both in navigation and in weapon delivery - have made it increasingly possible to destroy particular, militarily relevant targets with increasing precision. Put differently, technology increasingly provided the opportunity to better protect non-combatants. The upshot of Thomas's account of the history of aerial bombing is that this possibility was embraced: the available technology was deployed in a manner that maximised non-combatant protection. Wheeler makes similar claims about the 1999 NATO operation in relation to Kosovo. He suggests that 'compared to past conflicts, Kosovo was a very clean war in terms of the deaths of non-combatants' (2004: 197). After the operation, US Secretary of Defense William S. Cohen and Chairman of the Joint Chiefs of Staff General Henry H. Shelton claimed that it had been 'the most precise and lowest-collateral damage air campaign in history'. 5 This was, Wheeler argues, because of two factors: the close involvement of 
military lawyers in the targeting process and, crucially, the use of precision-guided munitions (PGMs) which had increased to 35 per cent from 8 per cent in the 1991 Gulf War. He claims that 'the unprecedented accuracy of these weapons significantly reduced collateral damage' (2004: 197).

According to these accounts, there has been not just a change in technology, but one in approach (see also Kahl, 2007: 14). Avoiding 'collateral damage' has become more central to the target selection and review process, with increasing involvement not only of senior military commanders but also of military lawyers and civilians. ${ }^{6}$ Thomas (2001: 170) claims that 'attitudes concerning the appropriate conduct of war have changed.' These changes, which are in tune with a zeitgeist that requires the reduction of human risk (Coker, 2001), have arguably been made easier by the technological improvements in weapon precision. For technological progress appears to make it possible to achieve what is ethically desired - noncombatant protection - without compromising military effectiveness. Martin L. Cook (2004: 34) notes that the development of smart weapons has allowed the US military to return to greater compliance with international law: 'The moral need to do so [...] was part of the reason; but so, of course, was the fact that munitions that hit what they are aimed at with consistency and regularity are more militarily effective.' The attractiveness of precisionguided weapons lies therefore not least in apparently making less pronounced the trade-off between achieving military aims and endangering non-combatants. According to Wheeler (2002: 210), the 'development of precision-guided weapons in the last decade has opened up new possibilities for reducing the risks of civilian casualties without sacrificing military effectiveness', thereby making less stark the difficult moral choices decision-makers have to make in warfare (Wheeler, 2002: 216). 
Technological change has not only enabled a more serious focus on collateral damage avoidance; it may be seen to have demanded it. For once precision is possible, it becomes politically imperative (Shaw, 2005: 35). Levels of collateral damage that may have been acceptable in the past, no longer are when high-tech weapons are available. Andrew J. Bacevich (1996) points out that '[a]s precision increases, so do expectations, constantly "raising the bar" of acceptable performance.' Technology and the change in attitudes that requires greater non-combatant protection thus go hand in hand. In Thomas's words (2001: 172), technology has 'created pressure to be good by removing a possible excuse for being bad.' This seems to be a thoroughly positive development and indeed a happy coincidence. It is good to be able to protect non-combatants (whilst still fighting wars) and sophisticated technology not only makes it possible to do just that; its existence arguably exerts pressure to improve civilians' protection. In Farrell's view, we are even witnessing a fortuitous coming together of technology and morality, as enshrined in international law: ${ }^{7}$

For the most part, Western militaries do go to considerable lengths to avoid causing collateral damage even though the inadvertent killing of civilians is permitted under international law. In part, this is a happy marriage of hardware and software; that is to say, Western technological prowess and Western-derived norms of international law (Farrell, 2005: 179).

This view is seductive. Much like the appeal of driving a car that consumes less fuel in order to 'protect the environment' instead of changing behaviour and cutting down on journeys by car, high-technology weapons seem to offer a technical fix for an ethico-political predicament. We don't much like the idea of killing people, and these weapons seem to allow us to have wars whilst still doing our bit with respect to the protection of non-combatants. 
The notion that technological progress may help us to be more ethical is not only appealing; it is also, on the surface, persuasive. After all, more precision is better. Or is it?

\section{Precision in Practice}

In the story about the improving precision of weaponry, the military appears increasingly in control of the devastation it causes. At the same time, claims made about the West's recent military operations underline the measures taken to avoid civilian casualties. The United States allegedly relies more and more on legal advice (Wheeler, 2002: 211; Kahl, 2007: 16-18 and 40-1). More broadly, US Department of Defense spokesperson Victoria Clarke claimed that in Operation Enduring Freedom US forces 'take great care in [their] targeting process to avoid civilian casualties.' ${ }^{8}$ In a briefing on 'Targeting and Collateral Damage' in Iraq, US Central Command outlined the processes in place to ensure that collateral damage would be limited. The briefing started with quotations by President George W. Bush, such as: 'We will try in every way we can to spare innocent life. The people of Iraq are not enemies' (US Central Command, 2003: slide 2). Whilst the briefing acknowledged that '[c]ollateral damage and unintended casualties occur also as a result of weapon system malfunction, human error, and the fog of war' (US Central Command, 2003: slide 3), it was designed to outline how US forces go about preventing such eventualities (see also Conetta, 2004: 18). The briefing underlined the legitimacy of strikes on, for example, dual-use facilities, but noted the aim of minimising non-combatant casualties, even where they might be permissible under international law. The gist of these claims is, then, that the US is making the most of the considerable precision of its weapons in order to ensure the protection of non-combatants.

'Precision' weapons are, however, inherently imprecise. A certain level of imprecision is indeed part of the definition of precision. As Carl Conetta (2004: 20) explains, the 'precision of weapon delivery systems is typically expressed in terms of Circular Error Probable (CEP), 
which is the radius of a circle centered on an aimpoint within which some percentage usually 50 percent - of weapons fired at the aimpoint will fall.' Thus, the precision claimed for a weapon is, even under test conditions, normally only achieved every other time. So, for example, if a weapon is said to have a CEP of 10 meters, then every other time it is fired in a test the weapon will land within a 10 meter radius of the designated target. In the other 50 per cent of cases, it will land somewhere else, more than 10 metres away from the target. These 50 per cent are ignored in determining the precision claimed for the weapon.

'Precision-guided munitions' (PGMs) involve a guidance system that allows for the weapon to be steered towards the target. Laser-guided and satellite-guided weapons are the most significant in contemporary warfare. Laser-guided systems rely on the target being marked or 'painted' by a target designator whereas satellite-guided systems rely on GPS (Global Positioning System). Laser-guided weapons require 'a clear line of sight between the bomb's laser seeker and the laser spot-beam designating the target, which is not possible under adverse weather conditions [rain, clouds, dust, etc]' (GlobalSecurity.org, 2007b; Stone 2007: 139-40); GPS-guided weapons may be used in any weather conditions. Whilst both systems make these weapons far more precise than unguided bombs, GPS-guided weapons are less accurate than laser-guided weapons.

What concerns Conetta is the extent to which GPS-guided weapons remain inaccurate. In his report on Operation Enduring Freedom in Afghanistan (2002), he highlights that the operation

failed to set a new standard for precision in one important respect: the rate of civilians killed per bomb dropped. In fact, this rate was far higher in the Afghanistan conflict -- perhaps four times higher -- than in the 1999 Balkans war. In absolute terms, too, the civilian death toll in Afghanistan surpassed that incurred 
by the 1999 NATO bombing campaign over Kosovo and Serbia; indeed, it may have been twice as high.

Conetta suggests that one of the factors contributing to this outcome, aside from the mission objectives and tactical and operational features of the campaign, were the weapons used and their technical characteristics. He points to the increasing use of the less accurate GPS-guided weapons as a problem:

Under test conditions, JDAMs [Joint Direct Attack Munitions] have been able to reliably achieve a Circular Error Probable (CEP) of approximately 10-13 meters -meaning that fifty percent of the JDAMs dropped will hit within 32-42 feet of their programmed coordinates. By comparison, laser-guided bombs routinely achieve CEPs of 3-8 meters. Even a difference as small as an 8-meter versus a 10-meter CEP equates to being able to put 50 percent of expended weapons within a 2100 square foot circle versus being able to put them in a circle of 3300 square feet. Should an intended target sit among a cluster of buildings, the difference between these two circular areas is significant. And, of course, in either case 50 percent of the weapons fall outside the circles (Conetta 2002: section 3; see also GlobalSecurity.org 2007a).

Thus, GPS-guided weapons are significantly less precise than laser-guided weapons. It is important to consider what all this means when these weapons are being used to attack actual targets. In some contexts, such as desert warfare, a lack of precision may mean simply a wasteful expending of weapons; in urban contexts, and this has been relevant in recent operations such as the war in Iraq, it almost invariably means collateral damage, particularly non-combatant casualties. The margin of error of 10-13 metres is fairly imprecise in an urban area (see also Conetta, 2004: 24); adjacent buildings as well as publicly accessible spaces - 
such as quite simply the street - will invariably be within the target area unless the size of the target itself exceeds the 13 metre radius and the two can be made to overlap completely. Crucially, half of the bombs that are fired are not even expected to land within that circle.

Moreover, the margin of error is often much greater. CEP normally already takes into account sources of error inherent to the systems. Beyond these, Conetta (2004: 23) notes four factors that may add to errors: intelligence errors; mechanical or electronic malfunctions; human error by pilots or ground controllers; and certain atmospheric conditions. The 13 metre radius is measured from the designated aimpoint. It does not, however, account for any potential discrepancy between the identified aimpoint and the location of the actual target. An example is useful to illustrate what is at stake. The GPS used to locate so-called leadership targets in Iraq was that of their satellite phones. That is, the phone was the target: no information was usually available on who was carrying it. But even assuming that the correct person was carrying the phone, the margin of error of these strikes was much larger than the CEP of the weapons employed suggests. The GPS information provided by the satellite phone system was only accurate within a radius of 100 metres (328 feet) (Human Rights Watch, 2003: 24). In other words, there was a 1 in 2 chance that the weapon would land within 10-13 metres of the target coordinates used, but the location of the satellite phone was not actually known with anything like that level of accuracy: it could have been anywhere inside a circle with a radius of 100 meters. Thus, despite the accuracy of the weapon, there was no way of telling whether the phone would be hit, much less whether the actual target - the Iraqi leader - would be (Human Rights Watch, 2003: 25).

Many of the spectacular 'mistakes' in recent wars have indeed not been due to weapon failure but - or so it was claimed - to intelligence failure. In the 1991 Gulf War the Al Firdos bunker was bombed and destroyed because it had been identified as an Iraqi command-and- 
control centre. However, it had also served as a shelter for civilians, and over two hundred were killed. This was seen as a public relations disaster, even though those ordering the destruction had been unaware of the civilians' presence (Thomas, 2001: 87-9). The infamous bombing of the Chinese embassy in Belgrade was a result not of weapon imprecision but of faulty information gleaned from outdated maps. J. Marshall Beier (2006: 267; see also Conetta, 2004: 23) points out that 'although the bombs fell squarely on the building at which they were "aimed," that building turned out not to be the FDSP [the Yugoslav Federal Directorate for Supply and Procurement] but the Chinese embassy.' In Afghanistan, finally, warlords apparently called in strikes on their rivals, identifying them as Taliban; there is evidence that "rival factions deliberately provided false intelligence to the US in order to bring down air strikes against their enemies' (Wheeler, 2002: 214; see also Owens, 2003: 611 and Conetta, 2002: section 6). Inaccurate information clearly poses a problem as a bomb taking out the wrong target with precision is not the desired result. Correct targeting information is of course vital for the successful operation of any weapon, but there may be particular issues resulting from the great distances from which PGMs may be used.

Thus, when Colin McInnes (2002: 81) claims that '[p]recision guidance coupled to highquality intelligence gathering enables individual buildings or even sections of buildings to be targeted with high confidence', we need to be mindful that 'high confidence' is far from a guarantee of success. Despite the spectacular imagery of precision-guided weapons zooming in on the correct target, their use does not automatically mean either that the target is hit or that there will be no collateral damage. Even smart weapons are inherently imprecise. They may also malfunction. Nor do they take the human - and therefore human fallibility - out of the equation. Human input remains significant not least because the weapon has to be instructed as to its target. Information is needed about what, or rather where, the target is. However precise the weapon may be, non-combatant protection will only ever be at best as 
good as the information used by those operating it. ${ }^{9}$ Non-combatants may, of course, also be killed when everything works exactly as planned: civilian casualties may be incidental, rather than accidental, and this is, under certain conditions, perfectly legal (Department of Defense, 2007).

\section{Precision and Protection}

Bombing has undoubtedly become vastly more precise. During the Second World War, the CEP of bombs would have been around 1,000 metres, whereas today it is more in the region of 10 metres. This means that the area at risk around the target has been reduced by a factor of 10,000 (Stone, 2007: 140). Moreover, even critics acknowledge that increasing attention is paid to the issue of collateral damage. Martin Shaw (2005: 15) admits that 'although there was much hyperbole', bombing in the 2003 Iraq War 'was more discriminating than in earlier campaigns.' Farrell (2005: 179) observes a convergence of norms of international law with precision military technology that has permitted Western militaries to 'limit civilian deaths during combat because they have unprecedented capability to create discriminate destruction.' Precision, in this view, is a good thing: it reduces the number of civilian deaths in combat. This seems to mean that a fortunate coming together of legal and ethical considerations with technological capability has delivered us from the hell of warfare.

Yet on a closer look matters appear less clear cut. 'Precision' in terms of effectively hitting the target is not the same as 'precision' in terms of not hitting anything else. In relation to the 2003 war in Iraq, Shaw (2005: 110) observes that '[f]ew doubted that bombing was very precise by historical standards, but the huge quantities of explosives inevitably caused many civilian deaths.' Part of the problem is, crudely put, that 'smart' bombs are also often large bombs (see Kahl, 2007: 22). And large bombs cause a lot of damage: 'most guided weapons in the 500- to 2000 -pound range are sufficiently powerful to routinely cause 
some degree of collateral damage' (Conetta, 2004: 24). This is because '[m]ost everything will be severely damaged, injured, destroyed, or killed within 20 meters of a 500-pound bomb blast and 35 meters of a 2000 lb. blast' (Conetta 2004: 25).

The distance from such blasts at which one would be safe is difficult to determine. The question of the 'safe distance' is different from that of the potential imprecision of the weapon captured in CEP. It is a complex issue involving the need to know the environment within which the bomb explodes: are there, for example, structures within the radius of the blast that might absorb some of its power? Where possible, computer simulations are employed to give a realistic assessment of the likely blast pattern (Graham, 2003). Traditionally, though, the military has used the notion of concentric circles around the point of impact in determining the safe distance, both for its own troops and non-combatants (David, 2001). When computer simulations are not available, rough notions of safe distances are still used. For 500 and 2,000 pound bombs these are typically set at about 500 and 1,000 metres respectively for unprotected troops (Conetta, 2004: 25). Thus, these weapons may well hit within a range of 10-13 meters of their aimpoint, but that does not mean that someone standing 14 metres away will be 'safe'. They would still be within the 'lethal radius' and they would certainly not be at the 'safe distance' set by the military for its own troops. ${ }^{10}$ In other words, the ability to destroy precise targets with efficiency and from a great distance does not equate to the ability not to destroy, or even protect, the surrounding area. The danger zone is much larger than the margin of error indicated by CEP.

This is particularly pertinent in the context of the 'precision gap' noted earlier between laser-guided weapons and the now increasingly employed satellite-guided weapons. From a military point of view imprecision means inefficiency. It means not only a wasteful expenditure of weapons but also necessitates putting troops in harm's way more frequently. 
There is, however, one obvious way to counter the effect of a bomb landing, potentially at least, at a greater distance from the designated target and that is to increase the destructive force of the bomb, its 'lethal radius'. As Conetta (2004: 25) notes, 'the terminal effects of big bombs serve to close the precision gap; they compensate for the lesser precision offered by GPS guidance.' Crucially, if the 'precision gap' between laser-guided and GPS-guided munitions has been addressed in the way in which Conetta alleges - by increasing the weapons' explosive force, then increased precision in terms of taking out the target is being achieved at the expense of precision in terms of not hitting anything else. In other words, the limits of precision indicated by CEP and noted in critical analysis by Wheeler, for example, are one thing. The destructive potential of such weapons is quite another. Conetta reminds us that the 'brute destructive power of these weapons is not ancillary to the recent success of precision attack, but central to it' (Conetta, 2004: 25). Not least as a result of that, 'there is an obvious difference between hitting one's intended target and not causing unintended casualties in the process' (Conetta, 2004: 19). This is crucial: the question of whether the designated target is successfully destroyed is not identical with the question of whether unintended casualties are caused.

Collateral damage is a problem in political terms and this issue is increasingly considered to be relevant to the success of military operations. McInnes (2002: 90; see also Farrell, 2005: 179) claims that 'the precision available to modern airpower allows collateral damage to be minimized and even casualties to the enemy's armed forces to be reduced. Such care is often seen as vital in ensuring domestic and international support for a campaign.' Noncombatant deaths are the most emotive aspect of collateral damage and their reduction through the stunning improvements in precision are crucial to claims about increasingly humane and ethical high-tech warfare. Because of increased precision fewer bombs are needed to take out a target and these are likely to fall very close to it. As a result, 'the level of 
collateral damage associated with any given attack will be very low by historical standards' (Stone, 2001: 140). For example, whilst the number of deaths caused by the bombing of German cities during the Second World War was in the region of 300,000 to 600,000 , the total number of civilians killed directly by the West in the Kosovo operation was about 500 (Shaw, 2005: 10).

Yet such comparisons are fraught with difficulty. If the argument is that PGMs reduce the level of non-combatant casualties one may legitimately ask what the comparative standard is. Is this a reduction per war, or per bomb, or per pound of TNT or perhaps per time period? What precisely does it mean to say that collateral damage is lower in current wars than it has been hitherto ${ }^{11}$ Whilst various precise statistical analyses are available, those who make claims about improved non-combatant protection unfortunately often remain vague about the comparative standard. ${ }^{12}$ It is not the purpose of the argument here to provide such a standard, but rather to point out that the comparative claims about casualty levels would need one, yet usually fail to provide it, and for good reason: it is not at all simple to determine what would constitute comparability in this context. Two issues that raise difficult questions for such comparisons are, firstly, whether the availability of PGMs enables practices that increase rather than decrease collateral damage in particular contexts and, secondly, which deaths should be counted in any comparison.

The discussion about the low collateral damage caused by 'smart' bombs sometimes seems to implicitly assume that the same targets are now being struck more effectively. Crudely put, where in the Second World War it was necessary to strike at cities as such, it is now possible to strike at particular military targets within cities, avoiding the kind of damage done to residential areas in the world war. What this way of looking at the issue does not seem to consider is that this new technology is also used to strike at different targets - or 
rather structures and indeed people that would not previously have been considered targets for aerial warfare - and what the consequences are of doing so. ${ }^{13}$ In other words, it is important to note that the capabilities of 'smart bombs' have made it possible to take on targets that would previously have been considered impossible to bomb from the air. This may increase the likelihood of collateral damage. Put differently, technological advances may lead to an increasing - or at least different - exposure of civilians, as did the possibility of aerial warfare in the first place.

Leaders hiding in residential areas, for example, have become targets for aerial warfare. It is possible to strike small targets from a distance and real-time information on the leaders' location is at times available. Ariel Colonomos argues that such 'targeted killings' fit within a wider discourse about the reduction of 'unnecessary suffering' (Colonomos, 2007). Put differently, such killings are framed ethically. They are about reducing non-combatants' deaths. Yet, according to Conetta, targeting leadership figures hiding in residential areas through the use of PGMs contributed to a higher rate of casualties in Afghanistan (2002: sections 2 and 6). Similarly, in Iraq, '[m]any of the civilian casualties from the air war occurred during U.S. attacks targeting senior Iraqi leaders' (Human Rights Watch, 2003: 20). This was not merely because residential areas are populated, but also because these targets were so-called 'emerging targets' or 'targets of opportunity' (see Weber, 2005). They had to be struck quickly, if they were to be struck at all, and apparently 'CENTCOM did not perform adequate collateral damage estimates for all of the leadership strikes due to perceived time constraints' (Human Rights Watch, 2003: 20). Moreoever, '[r]apid engagement may also preclude air crews taking time to derive and input GPS coordinates or laser-designate a target -- thus compelling a trade of accuracy for time' (Conetta, 2002: section 7). Thus, the faith in precision may encourage engaging targets in more problematic environments. ${ }^{14}$ These targets could have been taken out by different means, means that might have reduced the number of 
non-combatant deaths. As Sebastian Kaempf (2006: chapter 5) shows in relation to Afghanistan, various reports have argued that a greater use of ground troops and special forces in particular could have reduced the risks for civilians. This makes assessing the impact of precision weapons on non-combatant casualty levels tricky. Smith (2002: 359) claims that '[a]erial bombardment of civilian centers is almost inevitable in modern warfare.' This is not least because 'hi-tech tactics have had striking success in minimizing casualties, actually heightening the appeal of aerial bombing' (Smith, 2002: 361). Precision weapons may well cause fewer deaths per strike, but what does that mean if it is a strike that would not have been carried out in this way but for the smart bombs?

In Farrell's assessment (2005: 183), 'the US military could probably have done better' in terms of avoiding civilian deaths in Afghanistan. A great deal of debate has anyway been generated around the question of just how high or low the actual number of civilian deaths caused by coalition troops has been in recent conflicts (Roberts et al., 2004: 1857-64; Conetta, 2004; Kahl, 2007: 11-13; Zehfuss, 2007). No official count of the civilian casualties caused by coalition forces in Afghanistan or Iraq is available. ${ }^{15}$ A number of groups have produced their own count, using various methodologies. Yet no agreement has been reached over the actual non-combatant death toll, leaving any argument about the reduction of such deaths due to precision bombing on insecure ground.

This brings us to the second problem in establishing that PGMs reduce non-combatant casualties, namely the problem of counting itself. Iraq Body Count and Conetta's study 'Wages of War' are two well known attempts to provide casualty figures. ${ }^{16}$ As Shaw correctly points out, they pursue vastly different strategies. Whilst Iraq Body Count aims to make every death count, Conetta (2003: 3) argues that the precise figure is of little concern and that what is significant is a ballpark number. There are obvious practical difficulties 
associated with counting deaths in war and these are addressed and resolved in different ways by different studies. Yet what is significant is not just how to count the deaths, but which deaths to count in the first place. The idea that precision bombing produces a low death toll has some merit if the count is limited to immediate violent deaths. But this limitation is worth questioning. Whilst we may spontaneously think that there is a large difference between the deliberate incineration of Dresden in 1945 and the 'disabling' of particular aspects of the infrastructure in Baghdad in 1991, the consequences in terms of non-combatant deaths are not so straightforwardly different if long-term deaths are considered. As Stephen Graham (2004: 167) points out, 'strategies of deliberately attacking the systems and places that support civilian urban life have only become more sophisticated since the Second World War.' A large number of civilians, about 100,000 , are thought to have died as a result of the destruction of water purification and electricity plants in the 1991 Gulf War (Graham, 2004: 179; Downes 2008: 211, 226-7), a phenomenon which has been termed 'bomb now, die later'. 17

This issue may be further illustrated in relation to the more recent war in Iraq. Alexander B. Downes (2007: 234-6) elucidates and compares the methodology of Iraq Body Count, which is based on counting only deaths that can be verified by multiple news reports, and a study published in The Lancet, which is a cluster sample survey (Roberts et al., 2004). The former produces a reliable figure that is, however, necessarily an undercount. The latter, in contrast, estimates excess deaths as a result of the conflict through comparison with an estimated death rate prior to the hostilities. The figures arrived at are vastly different. Different things are counted. Whilst Iraq Body Count accounts for non-combatants deaths as a direct result of military action, The Lancet study is not limited to non-combatants and indeed to immediate military violence as cause of death. Neither, of course, assesses deaths caused by PGMs specifically. Yet the estimate arrived at by the Lancet study is important 
because it is one thing to say that PGMs cause less collateral damage; it would be an entirely other to assert that they reduce the level of non-combatant deaths. It is crucial to keep in mind this difference because, even if Farrell is right to say 'Western militaries can limit civilian deaths during combat' (2005: 179, emphasis added), this does not necessarily mean that fewer civilians die of the effects of war. Collateral damage assessments take into account only immediate damage at the point of impact. Smith (2002: 361) notes that it is 'striking', how 'civilian protection has been limited to immediate effects, not those that follow from infrastructural damage or from lingering results of war.' Deaths caused later on by unexploded bomblets, for example, and, more importantly perhaps, the effects of the destruction of essential infrastructure are not taken into account, nor are deaths caused by the disintegration of the civil order precipitated by the impact of high-tech warfare. Yet precision bombing may be seen to lead to these longer term deaths, raising further doubts about the non-combatant protection - and levels of ethicality - allegedly made possible by precision bombing.

\section{Precision and the Production of Ethics}

Smart bombs make it possible to hit targets precisely. Ideally, this should make it possible to keep non-combatants increasingly out of harm's way. The relatively low number of civilians killed directly by Western military action in recent operations indicates that this is working, at least to an extent. This has led a number of scholars to assert that precision weapons have in some way improved the ethicality or humaneness of warfare. Precision bombing indeed fits neatly with the idea that significance attaches to the protection of non-combatants. According to the just war tradition, for example, one of the key principles according to which the ethicality of conduct in war is assessed is non-combatant immunity or discrimination (Rengger, 2002: 358; Elshtain, 2003: 65), that is, the idea that civilians must not be targeted. This principle is not only central in much thinking about the ethics of war and indeed 
enshrined in international law by the Geneva Conventions; it also has some intuitive appeal. It is worth noting, however, that there is debate both about whether (see Holmes, 1989: 185-6 and Norman, 1995: 159) and, if so, about precisely why, it is unjust or unethical to target civilians.

One of the explanations of why it is permissible to target combatants relies on the idea that they are engaged in the business of harming the soldiers doing the targeting, unlike civilians, who are not (Norman, 1995: 168; Walzer, 1992: 43). In other words, combatants may harm those who harm them - and those who may harm them are enemy combatants. If this is the case, then ethical problems arise from the very high-tech warfare that is being judged so favourably, however. In the context of the Kosovo operation Ignatieff (2000: 161) argued that what he calls the 'tacit contract of combat throughout the ages has always assumed a basic equality of moral risk: kill or be killed', but that in operations such as the NATO Kosovo campaign this did not hold because the combatants on one side were unable to hurt those on the other. NATO's pilots were flying at an altitude where they could not be attacked with the sorts of weapons available to the military of the former Yugoslavia. In a similar vein, Walzer $(2004,101)$ argues that 'You can't kill unless you are prepared to die.' When one side fights with PGMs, putting their combatants out of range of the other side's combatants, this principle no longer applies. It is worth noting, perhaps, that historically fighting from a distance has been seen as unethical. ${ }^{18}$ There is certainly a risk, as James Der Derian notes, that in high-tech warfare 'one learns how to kill but not to take responsibility for it' (Der Derian, 2001: xvi). My point is, however, more limited: the use of weapons that put combatants out of their enemies' range invalidates one of the most common arguments for the permissibility of targeting enemy combatants, namely that they are in the business of harming the combatants doing the targeting. It is, in other words, not clear why protecting non-combatants should be a priority if enemy combatants are equally unable to inflict harm. 
Pursuing a different line of argument, some critics also suggest that non-combatant protection is in competition with, and loses out to, the so-called force protection imperative: when it comes to the crunch, instead of protecting non-combatants the US military in particular prefers to protect its own troops. This argument is again often made in relation to the Kosovo operation. ${ }^{19}$ Shaw (2005: 22; see also 86) claims that 'NATO risked civilian lives through high-altitude targeting errors in order to keep its aircrews safe.' It stands to reason that highly trained troops are valuable and that their protection is central to military practices. The state, moreover, may be seen to have a duty of care towards those who serve it. Yet the 'nub of the matter', in Shaw's view (2005: 135), is that 'the care taken for civilians was not only much less than the care taken for Western soldiers; it was undermined by a policy adopted to keep the latter safe.' More generally, Shaw decries Western war as what he calls 'risk-transfer war', that is, a form of war that transfers risks not least from its own military personnel to non-combatants (2005: 94-95).

Put differently, Shaw's charge is that the deciding ethical standard is force protection rather than non-combatant immunity and that the former actively undermines the latter. Kaempf (2006: chapter 5), however, points out that these arguments assert and assume that force protection meant greater dangers for non-combatants; they do not actually show that this is the case. It is not clear, for example, that flying lower in the Kosovo operation would have reduced the collateral damage incurred. As Kaempf (2006: 305) observes, where GPS-guided bombs are used, their accuracy would not have been affected by the aircraft's altitude. In relation to the more recent Operation Enduring Freedom he argues, nevertheless, that noncombatant protection could have been improved, not least by making more use of special forces (Kaempf, 2006: chapter 5). Thus, non-combatant protection was not the central - or certainly not the only - ethical standard in play, despite the way in which precision is produced as central to the alleged ethicality of precision bombing. 
Nevertheless, collateral damage avoidance is seen as increasingly important in political terms. Of course, even precision warfare (still) causes deaths and this is readily acknowledged. As Wheeler (2002: 207) notes, 'it is impossible - even with the most advanced precision weapons - to avoid the unintentional killing of the innocent'. It would certainly be naïve to assume that either politicians and military leaders promoting the benefits of precision bombing or indeed scholars painting these developments in a positive light are not aware of the limits of precision. Some level of deaths in war is inevitable, and all sides acknowledge this. The point, for those who praise precision, is that we are getting better at avoiding them, that we do our best to avoid them. Precision bombing is as ethical as it gets for the moment.

Yet we have to be mindful of the assumptions and implications of such a claim. Shaw (2005: 1) notes wryly that of course Western political leaders and thinkers 'do not intend to blow up civilians or non-combatants. That, if it happens, is by definition "accidental".' It is certainly how such deaths are presented to the public. This is also evident in Farrell's observation (2005: 160) about Kosovo: 'Mistakes were made, and NATO bombs did kill innocent civilians. ${ }^{20}$ Kahl (2007: 11) similarly notes that '[a]ccidents (both human and technological) will happen'. Given the 'great care' taken, such 'accidents' can only be marginal to the practice. Yet Wheeler (2002: 212) argues that construing non-combatant casualties simply as mistakes has problematic implications:

By framing the deaths of innocents as mistakes, the US sought to avoid the deeper moral and legal questions as to whether it was attacking legitimate military targets; whether such actions satisfied the proportionality rule; and whether its air and ground forces were placing themselves at sufficient risk in order to mitigate the horrors of war for innocent Afghans. 
One might add further questions, not least about the appropriateness of marshalling the idea of 'mistake' or 'accident' to explain away deaths caused by dropping extremely powerful bombs on residential areas. There seem to be two issues here. Firstly, framing civilian deaths as mistakes may turn incidental killings into accidental deaths. Whilst even the former are legal under certain conditions, an ethical assessment may need to differentiate between deaths that are foreseen and accepted as an element of a perfectly executed strike and those that occur because things have not gone according to plan. Secondly, one may however ask whether even accidents of the latter sort are quite as accidental as they appear.

Patricia Owens offers a sophisticated critique of how the notion of accident has been deployed. Non-combatant deaths caused by Western militaries can only ever be 'accidents' because they do not target civilians. Owens (2003: 596) notes the problem that '[b]ecause specific non-combatant deaths were not wilfully intended as unique events, they should be classed as "accidents"; the United States and its allies cannot be held responsible (or even criticised).' Owens (2003: 597) is concerned 'that civilian deaths are made permissible, not impermissible, when constructed as "accidents".' In other words, she examines how civilian deaths are 'legitimated' through the notion of accident and raises the question of where this leaves us in terms of assigning responsibility (Owens, 2003: 600).

Owens does not dispute the West's desire to avoid civilian casualties. Indeed, she acknowledges that 'a strong case can be made that adherence to standards higher than international law is increasingly the norm' (Owens, 2003: 606). Her aim is not to expose a tension between the standards claimed and actual targeting techniques, as do those who claim that force protection often overrules non-combatant protection. Rather what she is interested in is "to raise questions about the very idea that some acts are "beyond intention" and what that allows' (Owens, 2003: 606). She points out that we 'tend to view accidents as 
destructive, as unthought, random, events that occur against our best intentions' (Owens, 2003: 597, italics added). This is particularly problematic as civilian casualties, though unintended, are nevertheless often foreseeable (Kaempf, 2006: 303). If such casualties are knowingly accepted as part of a particular strike, we may argue that they are more properly seen as incidental, rather than accidental. But Owens significantly pushes the argument further and demonstrates the significance of acknowledging the extent to which even 'real' accidents are part of the practice itself. She suggests that a more profitable way of thinking through the issue would be for us to see 'accidents as integral dimensions of events themselves' (Owens, 2003: 597). That is, Owens dispenses with the distinction between accident and inherent imprecision (or indeed accident and foreseen incidental killings). In other words, in relation to what is being examined here, it is not possible to have precision bombing without collateral damage. If you choose to bomb, even with precision weapons, you always already choose to kill 'innocents'. Indeterminacy is even built into the system because the 'precision' as expressed in CEP, for example, is only ever expected to be reached every other time. The killing of innocents is a structural possibility; it is not an aberration, something that happens when things go wrong.

As Beier (2006: 267, italics added) points out, there is 'indeterminacy inherent in the use of precision-guided munitions (PGMs), even when the weapons themselves perform as intended.' This is not something that our attention is drawn to. Misses that remain a part even of 'precision' warfare are edited out of the story. Unless they lead to a spectacular 'mistake' and 'accidental' deaths, they are completely disregarded: the 50 per cent of bombs that fall outside the radius of precision are not acknowledged in determining the precision of the weapon nor are they pursued. They simply vanish. From a military point of view, this focus on whether or not the target is hit - rather than on what else might be hit in the process - makes some sense. Whilst concern with collateral damage exists, a bomb that misses its 
target is, above all, a failure. The point is not so much what it has destroyed instead, but that it has failed to destroy what it was meant to. ${ }^{21}$

Referring to Sankaran Krishna (1993), Beier notes, however, that bombs that miss their target still have 'to "arrive" somewhere' (2006: 271). So the point is not that they miss, or that we must focus more on the misses instead of the hits. The point rather is that every miss is also a hit. It just hits something or someone that was not meant to be destroyed. At this point in time the something or someone 'accidentally' destroyed tends to be outside the Western world (see Gregory, 2004, 2006) and this is arguably not without its own implications for an ethical assessment. Judith Butler (2004) has highlighted the way in which some deaths - those of Westerners - are counted very differently from others - those of nonWesterners. $^{22}$ This disregard for some lives - the lives of the non-combatants who are supposedly increasingly protected - betrays an attitude that does not seem compatible with the asserted understandings of ethics. Bacevich (1996) points out, moreover, that to those outside the US 'it may appear that Americans are asserting a double standard, denouncing as reprehensible the bomb placed in a parking garage (to which the United States may be particularly vulnerable), while deeming the disabling of an urban electrical grid by remote missile attack (which the United States is uniquely equipped to launch) to be altogether acceptable.' More civilians are likely to be affected by the latter, and arguably many civilians indeed died as a result of the 'disabling' of infrastructure in the 1991 Gulf War.

So the claim that, due to precision bombing, contemporary Western warfare produces fewer non-combatant deaths is problematic, but what is at issue is rather the suggestion that the changes in warfare occasioned by the use of precision weapons have ethical significance. In determining the validity of such a view, we might need to assess current 'performance' not in comparison to earlier times or indeed to dumb bombs, but with respect to what would be 
possible given the available technology. After all, ethics is not least about how we behave towards others. If claims are being made about the moral significance of precision bombing, we need to ask whether these weapons are being used in such a way as to limit the death toll as much as possible. More importantly, any such comparison might misconstrue the issue. Counting the dead raises fundamental issues. Shaw provides a good discussion of the problems associated with using statistics to critique war, although he does not engage with the significance of Iraq Body Count actually doing more than simply count (Zehfuss, 2007). There is, at any rate, a danger that accounting for the damage caused actually ends up justifying it. Counting the bodies in the pursuit of a critique of war not least seems to suggest that the level of non-combatant casualties is too high and therefore unacceptable, but this implicitly grants that there is a level that would be all right. Counting thus opens the door to the comparative argument that says that we are doing much better than in previous conflicts: we are on the right track, doing our best. Put differently, acknowledging the death toll of our contemporary wars is undoubtedly important, but it does raise the question of how much is too much. One may have doubts over how productive it is to enter a line of argument that, implicitly at least, involves us in setting a threshold of acceptability for the (civilian) death toll of wars. We may think that the question of the permissibility of wars is actually too important to be settled by arithmetic. In assessing our ethical performance, we might need to do more than count bodies.

Significantly, what is at stake in the claim that precision bombing is particularly ethical is not least the production of contemporary Western warfare as particularly ethical. Beier (2003: 420-1) notes that the Gulf War created a 'broad social expectation that non-combatants should be preserved from harm even when it might be necessary to destroy legitimate military targets located in populated areas.' Yet only few countries have the military capabilities necessary to live up to that expectation. In Beier's (2003: 413) words, 'the idea of reliably 
accurate PGMs has affected the discursive base of what count in the popular imaginary as legitimate warfare practices, such that only the most technologically advanced militaries can manage any pretense to meeting the standard.'

Even if this standard could be met by using precision weapons, it has to be remembered that they only make up part of the arsenal even of Western militaries. As noted earlier, the 1991 Gulf War created the misleading impression that all Western warfare today is 'precision' warfare (Thomas, 2001: 160). Even though this war is often seen as symbolising the technological revolution in warfare, we saw earlier that the percentage of such weapons used was then only 8 per cent. The percentage of precision-guided weapons has since increased, but only in the most recent conflicts have they accounted for the majority of weapons expended. In Operation Enduring Freedom the percentage has risen to 60 per cent (Wheeler, 2002: 212; see also Human Rights Watch, 2003: 16 and Conetta, 2002: section 2). In Iraq nearly two thirds of the bombs dropped by the US and the UK were precision-guided munitions (Human Rights Watch, 2003: 16). Conetta, however, alleges that the increase in so-called precision-weapons has in part relied on redefining what qualifies for that label. He notes that "GPS-directed weapons are not routinely called "precision" weapons at all, but “accurate" or "near precision" ones' (Conetta 2002: section 3). Indeed, Conetta argues that 'precision' used to be more precise: 'just a few years ago military professionals would not have described most of the guided weapons used in the Iraq war as "precision" instruments, reserving this adjective instead for systems with a CEP of 3 meters or less' (Conetta, 2004: 26).

It is anyway important to note the use of various types of more conventional weapons. Two points that have raised concern are the continuing significance and imprecision of artillery (see Conetta, 2003: 25; Wright, 2005: 152-3; Kahl, 2007: 20) and the use of cluster 
bombs, which are, not least, liable to leave unexploded ordnance. Even though the delivery of cluster bombs 'may be guided, they remain distinctly imprecise in the time dimension: five to 10 percent of their constituent bomblets fail to detonate, thus inadvertently (but predictably) becoming land mines that lie in wait for future victims' (Conetta, 2004: 24; see also Shaw, 2005: 112 and Kaempf, 2006: 299-300). Despite this, the US Central Command briefing in Iraq noted earlier mentioned only 'Precision Guided Weapons', as though no other weaponry was being used. In sum, the attention given to smart bombs and their supposed capabilities may obscure aspects of contemporary warfare that remain imprecise and highly destructive.

The focus on precision weapons is crucial to the representation of Western warfare as ethical and superior. Farrell (2005: 161) describes precision bombing as 'humane' without offering any argument or qualification. Although he acknowledges that civilian targets were bombed by NATO in the Kosovo operation, he notes how slow and reluctant NATO was to do so (2005: 156-7 and 162) and crucially dismisses the implications of this move in one sentence: 'In the context of a long and careful air campaign, such isolated desperate measures were excusable and excused' (Farrell, 2005: 162). Farrell does not clarify quite why these measures were excusable. This successive inclusion of increasingly 'more civilian targets' to achieve the objectives of the campaign in Kosovo (Wheeler, 2004: 189) might in contrast be seen to raise doubts about whether such bombing is ethical or, at least, about whether the protection of non-combatants is really as central to military practices as is being claimed.

It certainly seems to be problematic to suggest, as Kahl (2007: 42, emphasis added) does, that the United States is increasingly relying on 'expensive weapons systems designed to limit civilian casualties.' It seems more likely that these weapons are designed to efficiently take out targets. And this is not without consequences. As John Stone points out, improvements 
in accuracy have made war a more viable option, not least because 'the application of IT to warfare is understood to be producing a technical fix to the problem of civilian casualties' (2007: 134). Conetta (2003: 43) similarly notes the danger that the promise of new warfare capabilities may serve 'as a rationale to wage more wars.' He claims that 'the notion that US precision attack capabilities make it possible to wage war with a minimum of civilian casualties has figured centrally in public consideration of America's recent wars' (Conetta, 2004: 15). Inasmuch as the idea that Western militaries are able to protect civilians is an illusion, this is deeply problematic. The fundamental concern therefore is what (faith in) precision enables. In precision warfare civilians' deaths are regrettable accidents and, according to Owens (2003: 616), 'describing civilian casualties as "accidents" forms an integral part of the project of justifying war.'

In discussing the illusion that people do not or should not get killed in contemporary wars, Coker (2001: 3) observes that 'the Western world seems intent on re-marketing or revaluing' war. Precision bombing is part of this trend. The danger of 'precision' bombing is therefore not least that it produces a particular kind of warfare as ethical and thereby legitimates and arguably even encourages war. This is problematic because of the issues raised about what precision actually amounts to, but also because it relies on a prior assumption about the ethicality of discriminate destruction and killing.

\section{Conclusion}

This article started out by observing the increasing precision of aerial bombing, but then proceeded to demonstrate the complexity of the question of the implications of these developments in terms of protecting non-combatants, let alone any notions of ethical warfare. Conetta $(2004,19)$ argues that 'the two standards upon which expectations about the new warfare are based - weapon precision and care in targeting - do not reflect actual casualty 
and damage outcomes on the battlefield.' According to Conetta, particular targeting practices, especially those involving the use of GPS and targeting political leaders with precision bombs, have increased rather than decreased non-combatant casualties. Crucially, greater efficiency in hitting what you want to hit is not the same as being able not to hit what you do not want to hit. Conetta $(2004,28)$ therefore questions 'any facile correlation of precision weapon use and minimum possible casualties'. In his words, '[m]ore of the one does not necessarily mean less of the other.'

Yet, despite the doubts over the precise impact of developments in weapon technology on casualty figures and about what may be counted and compared, one might still think that the name of the game is improving precision: if only we could bomb entirely precisely, war would be just fine. But would absolute precision, if it were possible, be the answer to the dilemmas posed by war? Both for Shaw and for Owens this is the wrong question: the point is that absolute precision is, precisely, impossible. Shaw $(2005,137)$ argues forcefully that it 'is time to face the truth that war and civilian safety are not generally compatible' and therefore to seek alternatives to war (Shaw, 2005: 141). Life always interferes. And whilst we strive for perfect precision, assuaging our consciences by reminding ourselves that we mean well and that we do our best, we continue to kill. Put differently, the production of us as ethical because we bomb precisely relies on a curious fusion of intent and outcome, a fantasy of control. Whilst the idea of an ethics based on non-combatant immunity relies on intention - the claim that 'we' don't target civilians ${ }^{23}$ - and excuses non-combatant deaths by conceiving them as beyond intention, this blurs into the expectation of a particular outcome, a low death toll amongst non-combatants. Intent seems to translate almost directly into outcome - barring accidents - as we see ourselves as increasingly in control of the damage caused on the battlefield. Samuel Weber (2005: 18) points out that 'whereas targeting tends to generalize momentary control of a situation qua opportunity and project it indefinitely upon 
the future, it can wind up exposing itself all the more destructively to the unforeseen.' In other words, inasmuch as targeting projects itself towards the future, we are dealing with the unforeseen, with that which we are unable to control. Discussions of targeting with their focus on what we intend to hit and on collateral damage estimates seem to obscure a crucial aspect of targeting: at some point the weapon will be out of control. It will be beyond our intentions, in the realm of the future. We tend not to focus on this. In the faith in the technological possibility of precise targeting intentionality comes to be fused somehow with the expectation of success. This illusion is challenged but not shattered by incidences of ‘collateral damage' which are explained away as accidental, marginal, excusable.

The faith in precision bombing as making war more ethical seems curious in a number of respects. It seems to require an under-examination of the actual practicalities and implications of precision bombing and the ways in which 'precision' has been defined and redefined. $^{24}$ Of course, it is apparent that 'precision' does not mean war without noncombatant casualties. Even if total precision was possible, civilians could still find themselves in the line of fire as they might be at the aimpoint, working at an electricity plant, for example. What is more significant, however, is the underlying assumption that increases in precision can only be a good thing, that they somehow make war more ethical. This is problematic if such increases encourage more war or riskier targeting strategies within war. More fundamentally, it also seems to me to reveal a worrying failure to engage the ethicopolitical issues at stake. Put bluntly, the idea that increased precision means increased ethicality implies, as far as I can see, that ethics is if we only kill whom we mean to kill. This is not the place to offer a full-blown critique of the idea of non-combatant immunity. ${ }^{25}$ But, without delving into the complex literature on this issue, it can be noted that the celebration of precision warfare as ethical appears to pass over crucial questions, indeed seems to treat them as already answered: Why is it right for us to kill whom we mean to kill? And what does it 
mean to 'mean to' anyway? War necessarily involves killing and some believe politics necessarily involves war. But that does not mean that the problem of ethics can be reduced to justifying war and the killing within it. The idea that we do not 'mean to' kill those whom we know to be inevitably within range of the enormously destructive weapons we deploy 'with precision' can assuage our conscience only at the price of not acknowledging the difficulty of the ethico-political issues involved. The problem of ethics is precisely that of confronting a question that does not have the sort of appealing answer that resolving the dilemmas of warfare through the technical fix of high-tech weaponry would provide. 


\section{References}

Bacevich, A.J. (1996) 'Morality and high technology', The National Interest 45.

Beier, J. Marshall (2003) 'Discriminating Tastes: “Smart” Bombs, Non-Combatants, and Notions of Legitimacy in Warfare', Security Dialogue 34: 411-425.

Beier, J. Marshall (2006) 'Outsmarting Technologies: Rhetoric, Revolutions in Military Affairs, and the Social Depth of Warfare', International Politics 43: 266-280.

Butler, Judith (2004) Precarious Life: The Powers of Mourning and Violence. London: Verso.

Cockburn, Alexander and Andrew Cockburn (1980) 'The Myth of Missile Accuracy', The New York Review of Books 27.

Coker, Christopher (2001) Humane Warfare. London: Routledge.

Colonomos, Ariel (2007) 'Precision in Uncertain Times: Targeting as a Mode of Justification for the Use of Force', in: David Chandler and Volker Heins (eds.), Rethinking Ethical Foreign Policy: Pitfalls, Possibilities and Paradoxes. London: Routledge.

Conetta, Carl (2002) 'Operation Enduring Freedom: Why a Higher Rate of Civilian Bombing Casualties', Project on Defense Alternatives, Briefing Report No. 13, 24 January 2002, $<$ http://www.comw.org/pda/0201oef.html $>2007,9$ September.

Conetta, Carl (2003) 'The Wages of War: Iraqi Combatant and Noncombatant Casualties in the 2003 Conflict', Project on Defense Alternatives, Research Monograph No. 8, 20 October 2003, <http://www.comw.org/pda/fulltext/0310rm8.pdf $>2007,9$ September.

Conetta, Carl (2004) 'Disappearing the Dead: Iraq, Afghanistan, and the Idea of a "New Warfare",, Project on Defense Alternatives, Research Monograph No. 9, 18 February 2004, < http://www.comw.org/pda/fulltext/0402rm9.pdf $>2007,9$ September. 
Cook, Martin L. (2004) The Moral Warrior: Ethics and Service in the U.S. Military. Albany: State University of New York Press.

David, Israel (2001) 'Safe Distances', Naval Research Logistics 48: 259-69.

Davis, Mike (2002) Dead Cities. New York: The New Press.

Department of Defense (2007) 'Collateral Damage', in: DOD Dictionary of Military Terms. $<\underline{\text { http://www.dtic.mil/doctrine/jel/doddict/data/c/01001.html }>2007, ~} 5$ September.

Der Derian, James (2001) Virtuous War: Mapping the Military-Industrial-MediaEntertainment Network. Boulder: Westview Press.

Downes, Alexander B. (2008) Targeting Civilians in War. Ithaca: Cornell University Press. Elshtain, Jean Bethke (2003) Just War Against Terror: The Burden of American Power in a Violent World. New York: Basic Books.

Farrell, Theo (2005) The Norms of War: Cultural Beliefs and Modern Conflict. Boulder: Lynne Rienner.

Garrett, Stephen A. (1993) Ethics and Airpower in World War II: The British Bombing of German Cities. New York: St. Martin's Press.

GlobalSecurity.org (2007a) 'Joint Direct Attack Munition (JDAM)', $<$ http://www.globalsecurity.org/military/systems/munitions/jdam.htm $>2007,30$ September.

GlobalSecurity.org (2007b) 'What's New With Smart Weapons', $<$ http://www.globalsecurity.org/military/systems/munitions/intro-smart.htm> 2007, 30 September.

Graham, Bradley (2003) 'Military Turns to Software to Cut Civilian Casualties', The Washington Post, 21/02/03, A18. 
Graham, Stephen (2004) 'Postmortem city: Towards an urban geopolitics', City 8: 165-196.

Grayling, A.C. (2007) Among The Dead Cities: Is the Targeting of Civilians in War Ever Justified? London: Bloomsbury.

Gregory, Derek (2004) The Colonial Present: Afghanistan, Palestine, Iraq. Oxford: Blackwell.

Gregory, Derek (2006) “"In another time-zone, the bombs fall unsafely...”: Targets, civilians and late-modern war', The Arab World Geographer 9: 88-111.

Herold, Marc W. (2002) 'US Bombing and Afghan Civilian Deaths: The Official Neglect of “Unworthy” Bodies', International Journal of Urban and Regional Research 26: 626634.

Holmes, Robert L. (1989) On War and Morality. Princeton: Princeton University Press.

Human Rights Watch (2003) Off Target: The Conduct of the War and Civilian Casualties in Iraq, April $2003<\underline{\text { http:/hrw.org/reports/2003/usa1203/usa1203.pdf }>2007,11}$ September.

Ignatieff, Michael (2000) Virtual War: Kosovo and beyond. London: Chatto \& Windus. Kaempf, Sebastian (2006) Wrestling under conditions of asymmetry: US warfare and the trade-off between casualty-aversion and civilian protection. Aberystwyth: University of Wales, PhD thesis.

Kahl, Colin H. (2007) 'In the Crossfire or the Crosshairs? Norms, Civilian Casualties, and U.S. Conduct in Iraq', International Security 32: 7-46.

Krishna, Sankaran (1993) 'The Importance of Being Ironic: A Postcolonial View of Critical International Relations Theory', Alternatives 18: 385-417. 
MacKenzie, Donald (1990) Inventing Accuracy: A Historical Sociology of Nuclear Missile Guidance. Cambridge: The MIT Press.

McInnes, Colin (2002) Spectator-Sport War: The West and Contemporary Conflict. Boulder: Lynne Rienner.

Norman, Richard (1995) Ethics, Killing and War. Cambridge: Cambridge University Press.

Owens, Patricia (2003) ‘Accidents Don’t Just Happen: The Liberal Politics of HighTechnology “Humanitarian” War', Millennium: Journal of International Studies 32: 595616.

Rengger, Nicholas (2002) 'On the just war tradition in the twenty-first century', International Affairs 78: 253-63.

Roberts, L. et al. (2004) 'Mortality before and after the 2003 invasion of Iraq: cluster sample survey', The Lancet 364: 1857-64.

Schmitt, Michael N. (2002) 'Law, Policy, Ethics and the Warfighter's Dilemma', Journal of Military Ethics 1: 113-124.

Shaw, Martin (2005) The New Western Way of War: Risk-Transfer War and its Crisis in Iraq. Cambridge: Polity Press.

Smith, Thomas W. (2002) 'The New Law of War: Legitimizing Hi-Tech and Infrastructural Violence', International Studies Quarterly 46: 355-374.

Stone, John (2007) 'Technology and the Problem of Civilian Casualties in War', in: Brian Rappert (ed.) Technology and Security: Governing Threats in the New Millennium. Basingstoke: Palgrave.

Thomas, Ward (2001) The Ethics of Destruction: Norms and Force in International Relations. Ithaca: Cornell University Press. 
Tsipis, Kostas (1985) Understanding Nuclear Weapons. London: Wildwood House.

US Central Command (2003) 'Targeting and Collateral Damage' (05 March 2003), $<\underline{\text { http://www.defenselink.mil/dodcmsshare/briefingslide/90/030305-D-9085M-010.pdf }>}$ 2007, 11 September.

USAF Intelligence Targeting Guide (1998) Air Force Pamphlet 14- 210 Intelligence (1 February 1998), < http://www.fas.org/irp/doddir/usaf/afpam14-210/part00.htm $>2007,5$ October.

Walzer, Michael (1992) Just and Unjust Wars: A Moral Argument With Historical Illustrations, $2^{\text {nd }}$ edition. New York: BasicBooks.

Walzer, Michael (2004) Arguing about War. New Haven: Yale University Press.

Weber, Samuel (2005) Targets of Opportunity: On the Militarization of Thinking. New York: Fordham University Press.

Westhusing, Ted (2002) 'Targeting Terror: Killing Al Qaeda the Right Way', Journal of Military Ethics 1: 128-135.

Wheeler, Nicholas J. (2002) 'Dying for Enduring Freedom: Accepting Responsibility for Civilian Casualties in the War Against Terrorism', International Relations 16: 205-225.

Wheeler, Nicholas J. (2004) ‘The Kosovo bombing campaign’, in: Christian Reus-Smit (ed.), The Politics of International Law. Cambridge: Cambridge University Press, 189-216.

Wright, Evan (2005) Generation Kill: Living Dangerously on the Road to Baghdad with the Ultraviolent Marines of Bravo Company. London: Corgi Books.

Zehfuss, Maja (2007a) ‘Subjectivity and Vulnerability: On the War With Iraq', International Politics 44: 58-71. 
Zehfuss, Maja (2007b) ‘The Tragedy of Violent Justice: The Danger of Elshtain's Just War Against Terror', International Relations 21: 493-501.

Zehfuss, Maja (2008) 'Killing Civilians: Thinking the Practice of War', Paper presented at the International Studies Annual Convention in San Francisco, www.isanet.org.

Zehfuss, Maja (2009), 'Hierarchies of Grief and the Possibility of War: Remembering UK Fatalities in Iraq', Millennium: Journal of International Studies 38. 
1 I would like to thank Dan Bulley, David Chandler, Stuart Elden, Vivienne Jabri, Peter Lawler, Patricia Owens, Véronique Pin-Fat, Steve Smith, Hillel Steiner, John Stone, Angie Wilson, the anonymous referees for the EJIR and the audiences at the International Studies Association in San Diego, at King's College and at Manchester for their insightful comments. 2 Whether it is significant that collateral damage may be incidental rather than accidental raises complex questions that are addressed later on.

3 The issue is complicated. Conventional wisdom has it that the US pursued 'countereconomy' targeting whilst the UK was engaged in 'countercity' targeting, but strategies changed over time and were never that coherent. See Farrell, 2005: 115; Grayling, 2007: chapter 2; Garrett, 1993.

$4 \quad$ The complex relationship between technology and targeting strategy, and the particular role the idea of accuracy plays in this, has been examined in detail in relation to nuclear weapons. MacKenzie, 1990; see also Tsipis, 1985.

5 William S. Cohen and Henry H. Shelton, Joint Statement on 'Kosovo After-Action Review', Hearings of Senate Armed Services Committee, 14/10/99, 1 quoted in Wheeler, 2004: 197.

6 On the targeting process in the US military see also Westhusing, 2002: 129; Schmitt, 2002; USAF Intelligence Targeting Guide (1998); Kahl, 2007: 16-18.

$7 \quad$ Farrell (2005: 135-6 and 163) argues that international (humanitarian) law constitutes moral codes.

8 'Fact Sheet: US Military Efforts to Avoid Civilian Casualties', US Department of State, 25 October 2001, quoted in Wheeler, 2002: 210 (emphasis added by Wheeler). 
9 The alleged Revolution in Military Affairs, of which high-tech weaponry is a part, depends on the availability of real-time information, the so-called 'transparent battlefield'. See, for example, Bacevich, 1996; McInnes, 2002: chapter 6.

10 For an illustration of this point see the table in Herold, 2002: 630.

11 Sometimes what seems to be alleged is a reduction per war, but this raises precisely the question of how to compare. Of course there were fewer civilian casualties in the Kosovo operation than in the Second World War, but we are not told how precisely we are to compare a bombing campaign of less than four months with one of more than four years. See Farrell, 2005: 181-2.

12 Kahl (2007: 15) and Downes (2008) offer clearly specified comparisons.

13 Note the argument in the context of nuclear weapons that what can be targeted depends on accuracy. MacKenzie, 1990; Tsipis, 1985: 102.

14 See also Kaempf, 2006: 301-2; McInnes, 2002: 137-8.

15 On General Tommy Franks's claim that 'We don't do body counts' and its context see Shaw, 2005: 115 .

16 www.iraqbodycount.net; Conetta, 2003.

17 Smith, 2002: 363 referring to Peter Kandela (1991), 'Bomb now, die later', The Lancet, 337: 967; also Farrell, 2005: 162.

18 Kaempf $(2006,117)$ notes that Greek warriors despised Persian archers and javelin throwers because they killed from a distance.

19 The force protection imperative was seen as central to the Kosovo operation. See Wheeler, 2004: 215.

20 McInnes also uses (2002: 67) the term 'mistake'.

21 Note Tsipis's definition (1985: 139) of the 'accuracy' of a nuclear weapon: 'By “accurate" we mean a weapon that has a high probability of destroying its target.' 
$22 \quad$ For an exploration and critique of Butler's argument see Zehfuss (2009).

23 This claim is itself problematic, but that is not at issue here.

24 This is again parallel to the problem of nuclear weapon accuracy where a

'counterforce' targeting strategy prevailed even though it was doubtful that missiles were accurate enough to make this strategy work. See Cockburn and Cockburn, 1980 and the fascinating MacKenzie, 1990.

25 I attempt such a critique in Zehfuss, 2008; see also Zehfuss, $2007 \mathrm{~b}$. 